\title{
Sustainable Life Cycle Management: Indicators to assess the sustainability of engineering projects and technologies
}

\author{
A.C. Brent ${ }^{1}$, C. Labuschagne ${ }^{1}$ \\ ${ }^{1}$ Chair in Life Cycle Engineering, Department of Engineering and Technology Management, \\ University of Pretoria, South Africa.
}

\begin{abstract}
Companies that compete globally are progressively more required to commit to and report on the overall sustainability performances of operational initiatives, i.e. undertaken projects or technological innovations. A prerequisite for aligning these operational initiatives with the principles of sustainable development is a clear understanding of the various life cycles that are involved and the interactions between these life cycles. Tools are also necessary to evaluate the sustainability of these integrated life cycles. A detailed examination has shown that the current indicator frameworks that are available to measure overall business sustainability do not effectively address all aspects of sustainability at project and technology management level. A new framework to evaluate the sustainability of projects and technologies in the manufacturing sector is subsequently introduced. An approach to develop indicators that are relevant for the criteria of the sustainability assessment framework are subsequently proposed in the context of the South African process industry. Furthermore, case studies are described whereby these indicators are currently being tested. The way forward to achieve truly sustainable Life Cycle Management (LCM) in the manufacturing industry is therefore outlined.
\end{abstract}

Keywords-Projects, Technologies, Business Sustainability

\section{INTRODUCTION}

Business, as one of the three pillars of society (the other two being government and civil society)[1], has a responsibility towards the whole of society to actively engage in the sustainability arena [2]. The pressure is therefore mounting for businesses to align operational processes with the three objectives of sustainable development [3]. The different types of drivers for the incorporation of sustainability into business practices have been identified and classified with respect to business' licenses to exist, operate and sell [4].

The International Institute for Sustainable Development (IISD) has subsequently suggested that businesses can gain a competitive edge, increase their market share, and boost shareholder value by adopting and implementing sustainable practices. This can be done by companies "adopting business strategies and activities that meet the needs of the enterprise and its stakeholders today, while protecting, sustaining and enhancing the human and natural resources that will be needed in the future" [5].
A sustainable company in industry thus does not exclude business development and profit, but rather guides itself along a route of environmental protection and social responsibility [6]. However, stakeholders are now demanding proof of the "sustainability" of companies by progressively demanding reports on the overall sustainability performances of operational initiatives such as undertaken projects or technological innovations. The aim of this paper is to propose methodologies to assess the sustainability of such operational initiatives in industry, i.e. to assess to what extend the operational initiatives are aligned with the principles of sustainable development. In order to do so, three questions must be answered:

- Which aspects of a technology or project must be assessed internally? The interaction of different life cycles from an industry perspective must be addressed.

- What must be considered and measured through such an assessment? A framework of sustainable development criteria, relevant for operational initiatives in industry, must be defined.

- How must these criteria be measured? Sustainable development indicators, through an assessment procedure, are introduced and discussed, specifically for the environmental and social dimensions of sustainability.

\section{THE INTERACTION OF DIFFERENT LIFE CYCLES FROM AN INDUSTRY PERSPECTIVE}

A prerequisite for aligning operational initiatives, such as undertaken projects or technological innovations, with the principles of sustainable development is a clear understanding of the various life cycles that are involved and the interactions between these life cycles [7]. Three distinct life cycles can be distinguished in industry [7]: the project life cycle, the asset or process life cycle (the life cycle of an implemented technology), and the product life cycle. A project in this context is viewed as a vehicle to implement a capital investment in a new or improved asset or technology. Each of these life cycles consists of various phases (see Fig. 1) [7].

The life cycles do nevertheless interact. For example, the product and asset life cycles interact, while the asset and the project life cycle also interact (see Fig. 2 and Fig. 3) [7]. These interactions of the different life cycles in industry have been described in detail elsewhere [7]. It 
can thus be concluded that if the sustainability of a project or technology is assessed, the impacts or consequences of the assets and products associated with the project or technology must be included in the assessment.

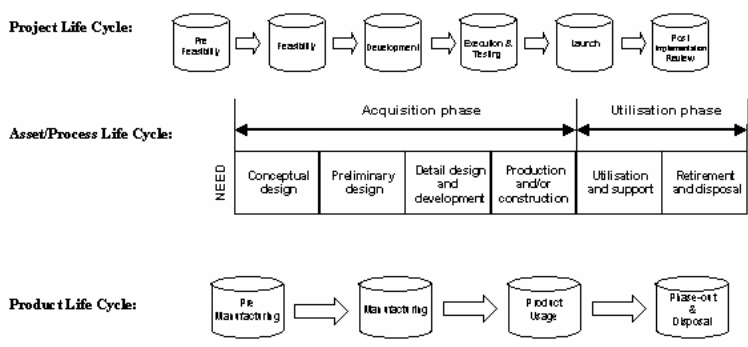

Fig. 1. Different life cycles fundamental to operations in industry [7]

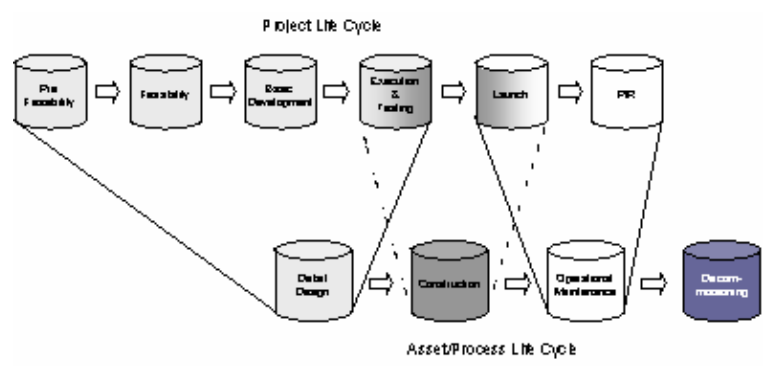

Fig. 2. Interaction between the project and asset life cycles [7]

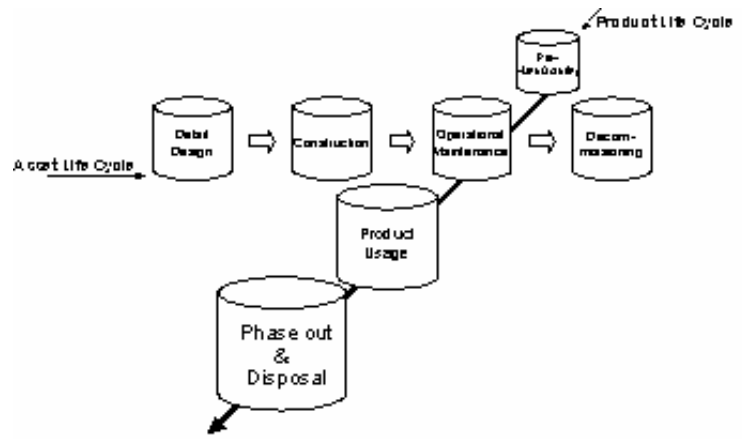

Fig. 3. Interaction between the product and asset life cycles [7]

\section{A FRAMEWORK OF CRITERIA TO ASSESS THE SUSTAINABILITY OF ENGINEERING PROJECTS AND TECHNOLOGIES IN INDUSTRY}

In order to assess sustainability performances in industry, a framework of appropriate criteria and associated indicators has to be defined. A number of current integrated frameworks, which are used to assess sustainability at an international, national, local or company level, have been reviewed to determine the relevant aspects (or criteria) that should be considered when assessing industry sustainability [8].
The proposed framework of appropriate criteria to assess the sustainability performances of operational initiatives in industry is shown in Fig. 4 [8]. The framework is divided into different levels to address the separate aspects of corporate responsibility strategy in terms of sustainability. The rationale of these levels has been described in detail elsewhere [8].

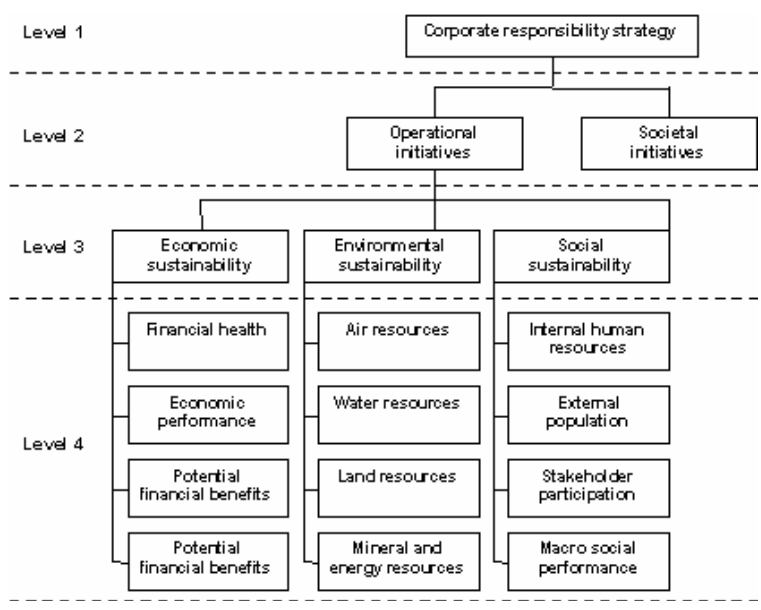

Fig. 4. Framework to assess the sustainability of engineering projects and technologies [8]

From a business perspective, the inclusion or consideration of social aspects in sustainability practices is marginal compared to the environment and economic dimensions $[9,10,11]$. Furthermore, the current state of the development of indicators or measurement procedures of the social performances of industry parallels that of environmental performances approximately 20 years ago [12]. Therefore, the social criteria of the framework were verified by a set of case studies [13]. For each of the three life cycle phases of assets (see Section II), i.e. construction, operation (which includes the product life cycle) and decommissioning, four case studies were chosen that aimed to determine the significant social impacts that may occur during these life cycle phases:

- The construction of four facilities in the process industry: a mine; an incinerator; petrol filling stations; and a gas pipe line across two countries.

- The operation of four chemical manufacturing facilities of which two are located in South Africa, one in Germany and one in the United States of America.

- The decommissioning of four process facilities: a cyanide manufacturing plant; a fibres manufacturing plant; a mine; and one unit within a process plant [13].

Project related documentation, pertaining to each of the case studies, were evaluated and personal interviews were held with project responsible individuals. The case studies concluded that certain social impacts are more important in certain phases, for example in the operation phase the main social concern is sensory stimuli, i.e. noise 
and odour, while employment opportunities are the major social concern in the construction and decommissioning phases. Furthermore, it has been evident that stakeholder participation is crucial in all life cycle phases. A presurvey has also been conducted in a South African company in the process industry to establish the suitability of the social criteria, as well as the relevance of the criteria in the framework, in terms of sustainable business practices and specifically project Life Cycle Management [14]. The case studies and pre-survey showed that the framework does include all of the relevant social criteria.

\section{Sustainable DeVElopMENT InDiCATORS OR ASSESSMENT PROCEDURES}

The identification of suitable indicators to measure the impacts of an operational initiative, i.e. an undertaken project or technological innovation, including the associated asset and product life cycles, on the three main sustainability dimensions (see Fig. 4) is dependent on the following three important points [7, 8]:

- The kind of information that is available at the point of assessing the sustainability performance of a specific operational initiative. For example, considering the life cycle of a technology development project in the process industry, detailed data may not exist in the early stages of the project on which to base an assessment, but may be available at later decision gates in the project appraisal process. Also, additional information gathering activities might have to be executed during individual phases in order to obtain the necessary sustainability data that is required by the indicators.

- The scientific methodology to translate the operational initiative information. There is currently no consensus on the exact procedure to assess the environmental performances of operational activities. However, work is ongoing in this field and methodologies have been proposed. With respect to the social dimension, there is little agreement on which criteria should be considered for social performances evaluations and methodologies are currently not practical for industry applications and business practices. In contrast, the methodologies for most of the sub-criteria of the economic dimension are reasonably well defined.

- The preferences of the specific project appraisers. Two approaches are currently under debate. On the one hand all impacts could be translated into financial terms [15], which is often understandable by decisionmakers. On the other hand, it is difficult, if not impossible, to place an economic value on all environmental and social impacts [16], and a qualitative route with decision analysis techniques, e.g. Multi-Criteria Decision Analysis (MCDA), could be used [17]. In some cases, a combination of these two approached have been proposed [18].
The advantages of Multi Criteria Decision Analysis (MCDA) techniques are that each decision criteria receives due consideration without necessarily converting all of the criteria to a common scale, e.g. in monetary terms. It is subsequently proposed to use an MCDA technique (for example the Analytical Hierarchical Process) to establish subjective weighting values for the different indicators (at level 4 of Fig.4) of the social, economic and environmental dimensions, and then to use the weighting values together with the indicator values for internal decision-making or for evaluation purposes. As far as indicators are concerned, the economic dimension has indicators (e.g. Return on Investment), which can be used directly. However, two procedures that are strongly based on LCA principles are introduced to derive indicators for the environmental and social dimensions.

\section{A. Environmental Resource Impact Indicators}

A quantitative procedure to calculate environmental Resource Impact Indicators (RIIs) has been developed, following the conventional Life Cycle Impact Assessment (LCIA) methodology [19]. Thereby, the following equation is applied to calculate the environmental impact indicators of an operational initiative on the level 4 criteria of the framework (see Fig. 4):

$$
R I I_{G}=\sum_{C} \sum_{X} Q_{X} \cdot C_{C} \cdot N_{C} \cdot S_{C}
$$

Where: $\mathrm{RII}_{\mathrm{G}}=$

Resource Impact Indicator calculated for a main resource group (air, water, land, or mined abiotic) through the summation of all impact pathways of Life Cycle Inventory (LCI) constituents on the resource group.

$\mathrm{Q}_{\mathrm{X}}=\quad$ Quantity of LCI constituent $\mathrm{X}$ released to or abstraction from a resource group.

$\mathrm{C}_{\mathrm{C}}=\quad$ Characterisation factor for a midpoint impact category $\mathrm{C}$ (of constituent $\mathrm{X}$ ) within the pathway. $\mathrm{N}_{\mathrm{C}}=\quad$ Normalisation factor for the midpoint impact category based on the ambient environmental quantity and quality objectives, i.e. the inverse of the ambient target state of the impact category.

And; $\quad S_{C}=\frac{C_{S}}{T_{S}}=\begin{aligned} & \text { Significance (or relative } \\ & \text { importance) of the midpoint impact }\end{aligned}$ category based on the distance-totarget method, i.e. current ambient state $\left(\mathrm{C}_{\mathrm{S}}\right)$ divided by the target ambient state $\left(\mathrm{T}_{\mathrm{S}}\right)$. 


\section{B. Social Impact Indicators}

A similar approach is proposed for the social dimension of sustainable development. However, in order to follow such an approach the following must be defined:

- The interventions of an operational initiative, including the associated product life cycle, on the social dimension, i.e. the social LCI of an operational initiative.

- The classified midpoint categories, with respective characterisation factors for the social LCI constituents.

- Measurement or equivalence units for the classified midpoint categories.

- Normalisation values for the social midpoint categories based on the target background social footprint in the society where an operational initiative will occur.

- Significance factors that are a function of the current background social footprint compared to the target background social footprint in the society where an operational initiative will occur.

Midpoint categories have been defined by mapping a list of identified possible social interventions in the process industry (which was a result of the case studies discussed in Section III) with the criteria at the different levels of the sustainability performances assessment framework [8]. Three measurement methods are proposed to express these defined midpoint categories in equivalence units (see Table 1):

- Established risk assessment approaches, which require a subjective evaluation of the probability of occurrence, the projected frequency of the occurrence, and the potential intensity thereof;

- Quantitative evaluation approaches, including, but not limited to, costs and direct measurements in society; and

- Qualitative evaluation approaches, which require appropriate subjective scales and associated guidelines, and have been proposed for the industrial ecology and streamlined LCA disciplines.

From the definition of the midpoint categories it is evident that the normalisation and significance steps will be constraint by what is practicably measurable within a society where an operational initiative (from an industry perspective) will typically occur. In this regard the availability of information will most definitely differ between developed and developing countries.

Furthermore, the projection of the social interventions of a project or technology may be problematic or at least differ from case to case.

\section{CONCLUSION}

This paper has provided an overview of the aspects of, or different life cycles associated with, a technology or project that must be assessed internally. Furthermore, a framework of sustainable development criteria, relevant for operational initiatives in industry, has been defined for such internal assessments. An assessment procedure, with associated sustainable development indicators, has also been introduced and discussed, specifically for the environmental and social dimensions of sustainability.

TABLE 1

MidPoint CATEGORIES AND MEAsuREMENT Methods TO EXPRESS EQUIVALENCE UNITS

\begin{tabular}{|c|c|c|}
\hline $\begin{array}{l}\text { Social Impact } \\
\text { Indicators } \\
\text { (SIIs) }\end{array}$ & Midpoint category & $\begin{array}{c}\text { Measurement } \\
\text { methods to } \\
\text { establish } \\
\text { equivalence } \\
\text { units } \\
\end{array}$ \\
\hline \multirow{4}{*}{$\begin{array}{l}\text { Internal } \\
\text { Human } \\
\text { Resources }\end{array}$} & $\begin{array}{l}\text { Permanent internal } \\
\text { employment positions }\end{array}$ & Quantitative \\
\hline & $\begin{array}{l}\text { Internal Health and Safety } \\
\text { situation }\end{array}$ & Risk \\
\hline & $\begin{array}{l}\text { Knowledge level / Career } \\
\text { development }\end{array}$ & Quantitative \\
\hline & $\begin{array}{l}\text { Internal Research and } \\
\text { Development capacity }\end{array}$ & Quantitative \\
\hline \multirow{13}{*}{$\begin{array}{l}\text { External } \\
\text { Population }\end{array}$} & Comfort level / Nuisances & Risk \\
\hline & Perceived aesthetics & Qualitative \\
\hline & Local employment & Quantitative \\
\hline & Local population migration & Qualitative \\
\hline & Access to health facilities & Quantitative \\
\hline & Access to education & Quantitative \\
\hline & $\begin{array}{l}\text { Availability of acceptable } \\
\text { housing }\end{array}$ & Quantitative \\
\hline & Availability of water services & Quantitative \\
\hline & Availability of energy services & Quantitative \\
\hline & Availability of waste services & Quantitative \\
\hline & $\begin{array}{l}\text { Pressure on public transport } \\
\text { services }\end{array}$ & Quantitative \\
\hline & $\begin{array}{l}\text { Pressure on the transport } \\
\text { network / People and goods } \\
\text { movement }\end{array}$ & Quantitative \\
\hline & $\begin{array}{l}\text { Access to regulatory and public } \\
\text { services }\end{array}$ & Quantitative \\
\hline $\begin{array}{l}\text { Stakeholder } \\
\text { Participation }\end{array}$ & $\begin{array}{l}\text { Change in relationships with } \\
\text { stakeholders }\end{array}$ & Qualitative \\
\hline \multirow{3}{*}{$\begin{array}{l}\text { Macro-Social } \\
\text { Performance }\end{array}$} & $\begin{array}{l}\text { External value of purchases / } \\
\text { supply chain value }\end{array}$ & Quantitative \\
\hline & $\begin{array}{l}\text { Migration of clients / Changes } \\
\text { in the product value chain }\end{array}$ & Qualitative \\
\hline & $\begin{array}{l}\text { Improvement of socio- } \\
\text { environmental services }\end{array}$ & Quantitative \\
\hline
\end{tabular}

The assessment procedure proposes to apply MCDA techniques with calculated indicators. The calculation of these indicators follows normal environmental LCIA methodologies, i.e. a midpoint category approach. Social midpoint categories have subsequently been introduced and further research is now required in order to determine which midpoint categories should form part of a sustainable project or technology LCM procedure.

Firstly, a survey in the South African industry will establish which social criteria are relevant at project level and which should rather form part of a corporate governance framework. Secondly, the application of the Delphi technique will establish which of the midpoint categories can be practically measured in the process industry, i.e. suitable information is available from within 
projects and the external environment. Lastly, case study information from a set of industry case studies (see Section III) will determine the ease of calculating the midpoint category values and determine whether the values are meaningful for decision-makers.

\section{REFERENCES}

[1] S.L. Wartick and D.J. Wood, International business and society. Malden: Blackwell, 1998.

[2] C.O. Holliday, S. Schmidheiny, and P.Watts, Walking the talk: The business case for sustainable development. Sheffield: Greenleaf Publishing, 2002.

[3] J.J. Keeble, S. Topiol, and S. Berkeley, "Using indicators to measure sustainability performance at a corporate and project level" Journal of Business Ethics, Vol. 44, pp. 149-158, 2003.

[4] F. Goede, The Future of $S H \& E$ in the process industry with the focus on products. Sasol Group Presentation, Department of Engineering and Technology Management, University of Pretoria, South Africa, 2003.

[5] International Institute for Sustainable Development, Deloitte $\&$ Touche and the World Business Council for Sustainable Development. (2004, June 30). Business strategies for sustainable development: Leadership and accountability for the 90s. [Online]. Available:

http://www.iisd.org/publications/publication.asp?pno=242.

[6] J. Hill, "Thinking about a more sustainable business: An indicators approach", Corporate Environmental Strategy, vol. 8 , no. 1 , pp. $30-38,2001$

[7] C. Labuschagne and A.C. Brent, "Sustainable Project Life Cycle Management: The need to integrate life cycles in the manufacturing sector," International Journal of Project Management, In Press

[8] C. Labuschagne, A.C. Brent and R.P.G. van Erck, "Assessing the sustainability performances of industries," Journal of Cleaner Production, In Press.

[9] S. Zadek, "Stalking sustainability," Greener Management International, Vol. 26, pp. 21-31, 1999.

[10] W. Visser and C. Sunter, Beyond reasonable greed: Why sustainable business is a much better idea. Cape Town: Human \& Rousseau \& Tafelberg, 2002.

[11] S. Roberts, J. Keeble and D. Brown, The business case for corporate citizenship. Cambridge: Arthur D. Little, Cambridge, 2002.

[12] J. Ranganathan, Sustainability rulers: Measuring corporate environmental and social performances. Sustainable Enterprise Perspectives, World Resources Institute Publication, 1998.

[13] C. Labuschagne, Chapter 5: Case Studies to verify framework, Working Paper no. 2004/01, Department of Engineering and Technology Management, University of Pretoria, 2004.

[14] C. Labuschagne, and A.C. Brent, "Sustainable Project Life Cycle Management: Aligning project management methodologies with the principles of sustainable development" Proceedings of the 2004 PMSA International Conference "Global Knowledge for Project Management Professionals", pp. 104-115, 2004.

[15] R.P.G. Van Erck, A monetary evaluation of the sustainability of GTL fuel production in South Africa. Master's thesis, Faculty of Technology Management, Technical University Eindhoven, 2003.

[16] R. Jansen, Multi-objective decision support for environmental management. Dordrecht: Kluwer Academic Publishers, 1992.

[17] J. Petrie, L. Basson, M. Stewart, P. Notten, and B. Alexander, "Decision making for design of cleaner processes: A Life Cycle Management perspective" Proceedings of the Firs International Conference on Life Cycle Management: Bridging the Gap between Science and Application, Copenhagen, Denmark, 2001.
[18] J.T. Winpenny, Values for the environment: A guide to economic appraisal. London: HMSO, 1991.

[19] A.C. Brent, “ A Life Cycle Impact Assessment procedure with resource groups as Areas of Protection.," International Journal of Life Cycle Assessment, Vol. 9, No.3, pp.: 172-179, 2004. 